$\underline{\text { April } 1928} \quad \underline{\text { Vol. XLIII., No. } 4}$

\title{
The Journal of
}

\section{Laryngology and Otology}

\author{
EDITED BY \\ A. LOGAN TURNER AND J. S. FRASER
}

\section{Contents}

The Alleviation of Chronic Deafness .

EDITORIAL

Deaf-Mutism with Bilateral Lesion of thè

AUDitory SENSORY AREAS

f J. S. Fraser isarah H. Nelson

Posterior (Mastoid) Drainage in Acute SuppuraTION OF THE MIDDLE-EAR

DAN MCKeNZIE

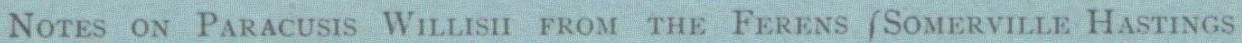
Institute of Oto-Laryngology . . $\{$ Gordon R. Scarff

The Surgical Approach to the Ethmoid . - C A. Verge

Cunical ReCORD :-

SECONDARY HemorRhaGe AFter Diathermy OPERATION . . . . .

E. A. Haltas

SOCIETIES' ProceEdings :-

Royal Society of Medicine-Section of Otology.

The American Laryngological Association.

Vienna Rhino-Laryngological Society.

ABSTRACTS :-

The Ear. The Larynx. Endoscopy for Foreign Bodies.

Seeing Sound: The Study of Speech and the Accurate Grafing of Speech Vibration.

Reviews of Books.

General Notes.

\section{Edinburgh: Oliver and Boyd London : 33 Paternoster Row}




\section{"They render fluids like smoke"}

is the description applied by the $L A N C E T$ to the

\section{Universal Vaporiser}

\section{And the "AERISER" (a smaller model)}

THESE remarkable instruments have the power to 1 subdivide solutions (whether volatile or nonvolatile) so finely that the vapour can be forced even into the most remote positions of the respiratory tract and middle ear, not excepting the air cells and nasal sinuses. And this is accomplished successfully without the use of steam or heat.

These instruments are largely used in the exhibition of "Neboline" Compounds, of which the formulæe are included in the Brochure entitled "The Treatment of Pulmonary and Bronchial

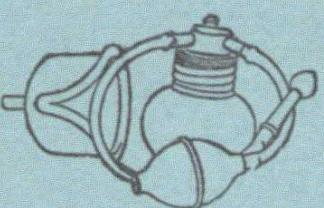

VAPORISER Affections," which will be posted to any member of the Profession on request.

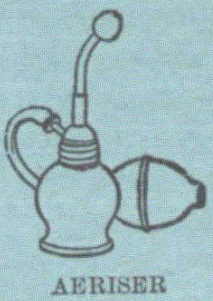

\section{OPPENHEIMER SON \& CO. LTD.}

179 Queen Victoria Street, London, E.C. 4

Manufacturers of "Roboleine," the Reconstructive Food which has been consistently prescribed for 20 years and used with the happlest results by Hospitals, Sanatoria, and Weifare Centres. 


\title{
A Memorandum to the Medical Profession
}

\author{
Upon the Sale of \\ Electrical Hearing Aids for the Deaf
}

An Explanation of a method of sale which protects the Deaf against the loss and disappointment entailed by the purchase of unsuitable Hearing Aids. This method of sale is popularly described as

\section{The FORTIPHONE 30=days Home Trial Plan}

The FORTIPHONE Home Trial Plan enables the deaf person, on payment of a small rental fee, to take the selected FORTIPHONE home for 30-days trial. Thus the deaf person is enabled to test the FORTIPHONE thoroughly, under every-day conditions in the home, in the street, in Church, theatre, and concert hall, before deciding to purchase. If the FORTIPHONE should fail to give the help anticipated, we exchange it or take it back at the customer's discretion.

The payment of the rental fee frees the customer, in the event of dissatisfaction, from any uncomfortable sense of obligation ; and he is, at the same time, safeguarded against the disbursement of the full purchase price until he has satisfied himself (uninfluenced by a professional "demonstrator") that the FORTIPHONE will be of real benefit to him.

After the purchase has been completed, care is taken to ascertain, from time to time, that the FORTIPHONE is being properly used and is giving satisfactory service.

\section{Approved and recommended by leading Aurists}

Full particulars will gladly be sent and arrangements made for $a$ trial of the Fortiphone, upon request.

Please write to

\section{FORT I PHONE L IMITED}

Sole Distributors of the FORTIPHONE for the Deaf and the SONOMAX Sound Amplifier

LANGHAM HOUSE (Dept. 9I)

308 REGENT STREET, LONDON, W. I 


\title{
The \\ Journal of Laryngology and Otology
}

(Founded in 1887 by Morrll Mackexzin and Norris Wolfandrs)

EDITED BY

\author{
A. LOGAN TURNER AND J. S. FRASER \\ ASSISTED BY \\ DOUGLAS GUTHRIE AND WALTER HOWARTH
}

1. Original Articles are accepted on the condition that they have not been published elsewhere.

2. Manuscripts should be typewritten, on one side only of the paper, and well spaced.

3. Galley proofs and engraver's proofs of illustrations are sent to the author. Corrections, which should be kept to a minimom, must be clearly marked and no additional matter should be added.

4. The order for reprints should be sent when returning galley proofs, and for this purpose specisl forms are supplied, on which the price of the reprints is stated.

5. Authors of Original Communications on Oto-Laryngology in other Joarnsls are invited to send a copy, or two reprints, to the Journat of Laryngology. If they are willing, at the same time, to submit their own abstract (in English, French, Italisn, or German) it will be welcomed.

6. Fditorial Communications should be addressed to "EDiTors, Journal of Laryngology, c/o Messrs Oliver and Boyd, Tweeddale Court, Edinbargh."

7. The Annual Subscription is Forty Shillings, post free, and is payable in advance.

8. Single Copies of back numbers, both of the present and the previous series, are on sale at Four Shillings each.

9. An Annual Snbscription can be commenced with any number of the Journsl, and the preceding numbers of the current year can be purchased at Four Shillings each.

\section{UNITED STATES OF AMRRIOA}

Orders for this Journal, for single parts or yearly subscriptions, can be sent either through a local bookseller, or to Messrs G. E. SrecherT \& Co., Bi-33 East 10th Street, New York.

\section{CENTRAL LONDON THROAT, NOSE, AND EAR HOSPITAL GIRI IT,S IITIN IROA D \\ (Near King's Cross Stations) \\ DAILY CLINICS. LECTURES ON FRIDAYS, 4 p.m. \\ DAILY CLINICS. LECTURES ON FRIDAYS, 4 p.m.
OVER II,000 NE W PATIENTS LAST Y EAR. 50,000 ATTENDANCES.
IN-PATIENT DEPARTMENT, 43 BEDS. In-Patient Operations Daily. \\ SPECIAL INTENSIVE COURSE OF LECTURES AND DEMONSTRATIONS (including Operative Surgery Course; Peroral Endoscopy Class and Pathology Class, especially suitable for D. L.O. Students), in co-operation with the Fellowship of Medicine, twice yearly-May and October. COURSE IN METHODS OF EXAMINATION \& DIAGNOSIS at frequent intervals. SURGEONB
Dr ANDREW WYLIE
Mr Nicol RanKin
Dr DAN MCKENZIE
Mr ARCHER RYLAND
Mr HAROLD KISCH
Mr F. W. WatKyn-Thomas
A88ISTANT SURGEONB
Mr C. Gill-Carey
Mr ARMOUR Brown \\ Mr J. D. MCLAGgan \\ CLINICAL AS8IBTANTS}

Are appointed from among those duly qualified gentlemen who have been enrolled as Post-Graduate Students of the Hospital.

\section{FEES}

For attendance on the practice of the Hospital-

Three months . . . 5 guineas | Six months. . . 8 guineas Special Intensive Course.-

Clinical Course, 65,5 s., Operative Surgery, $67,7 s .$, Endoscopy, 66, 6s., Pathology, $£ 4$, 4 s. 
Just Published. Second Edition. Fully Revised and Enlarged.

Demy svo, 464 pp. 234 Text Illustrations and 12 Plates (of which 8 are in colour). 20s. net, Postage 9d. DISEASES OF THE NOSE, THROAT, AND EAR For Practitioners and Students

Edited by A. LOGAN TURNER, M.D., LL.D., F.R.C.S.E. Consulting Surgeon, Ear and Throat Department, Royal Infirmary, Edinburgh J. S. FRASER, M.B., F.R.C.S.E. With the collaboration of

J. D. LITHGOW, M.B., F.R.C.S.E. and DOUGLAS GUTHRIE, M.D., F.R.C.S.E.

"May confidently be recommended for the use of students and practitioners." - Lancet. "Will prove of the greatest value."-Journal of Laryngology and Otology.

BRISTOL: JOHN WRIGHT \& SONS LTD. LONDON: SIMPKIN \& CO. LTD.

\title{
INSTRUMENTS AND EQUIPMENT FOR Examination of Ear, Nose and Throat, Operation on Tonsils, Adenoids, Mastoid, Nasal Septum
}

\author{
As supplled to and used in
}

FAR, YOSF AND THROAT DFPARTMENT, ROYAI INFIRMARY, EDINBURGH THH FDINBURGH HYE, FAR AND THROAT INFIRMARY, FTC., HTC.

$$
\text { AL8O THE CHEVALIER JACKSON INSTRUMENTS }
$$

\section{ARCHD. YOUNG \& SON, 57-61 FORREST ROAD, EDINBURGH} Surgical Instrument Makers to Royal Infirmary, Edinburgh

'Phone: 20609.

\author{
Telegrams: "Bandaze, Edinburgh," A.B.C. Code, sth Ed.
}

\section{DeVILBISS SPRAY No. 15}

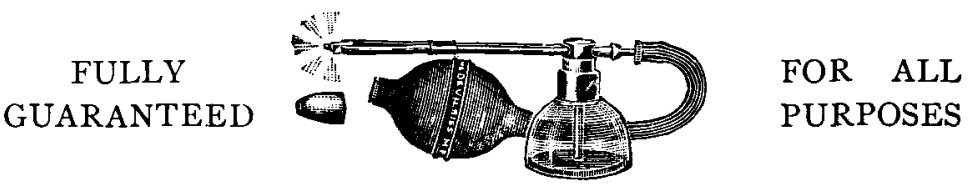

For Spraying the Nose and Throat with Olls and Aqueous Solutions

\section{Important}

The adjustable tip permits spraying in any direction, and is especially important when the bronchial tubes or the post-nasal cavities are to be treated.

When prescribing, please specify

"DeVilbiss Spray No. 15"

(of all Chemists and Surgical Instrument makers)

Complete illustrated Catalogue from

DeVILBISS, CO., LTD., WEST DRAYTON, MIDDLESEX 


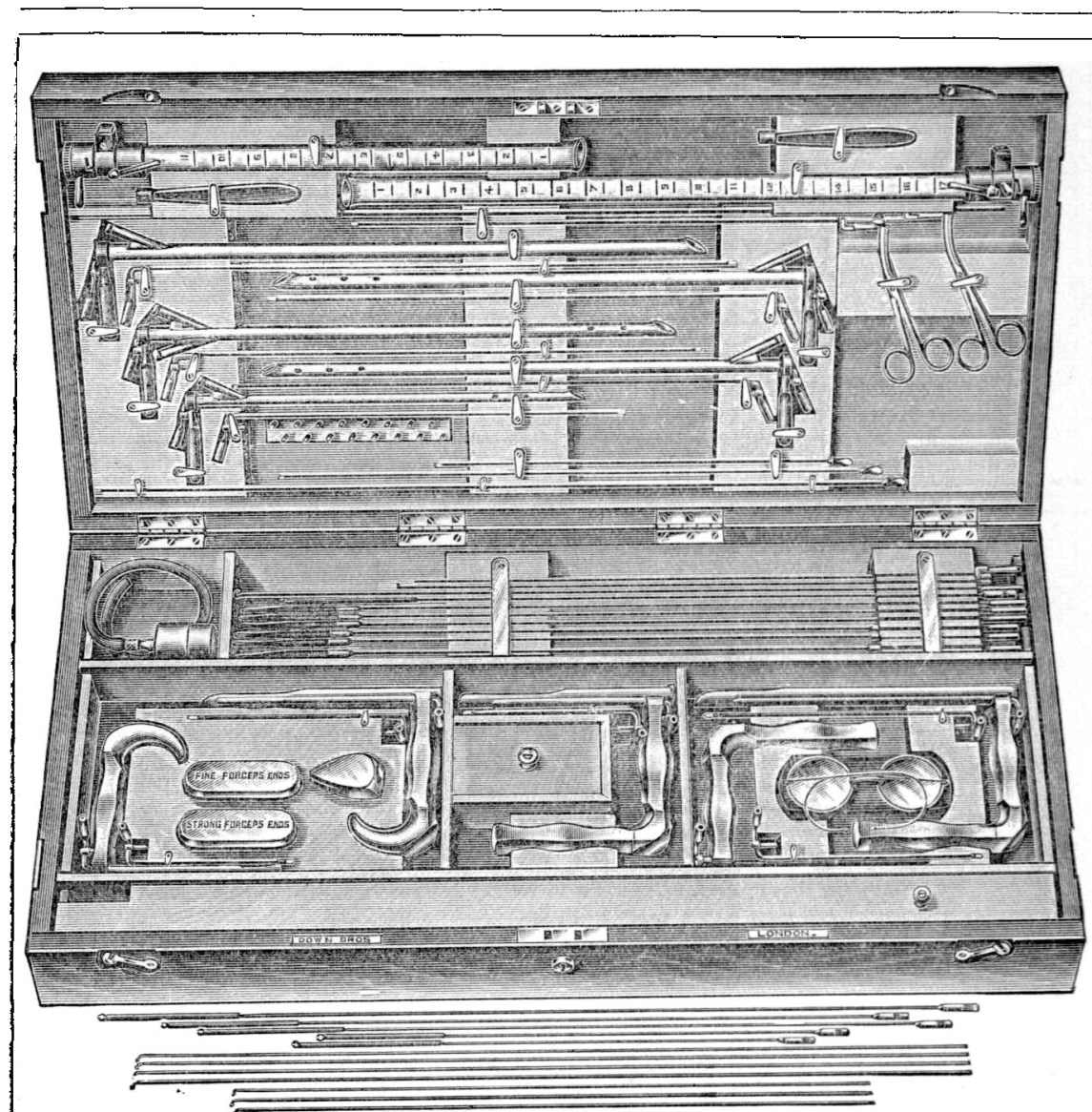

\section{CHEVALIER JACKSON'S INSTRUMENTS FOR ESOPHAGOSCOPY, LARYNGOSCOPY, AND BRONCHOSCOPY}

\section{New Models as made for Walter G. Howarth, F.R.C.S.}

Each Instrument is made in accordance with the details of Chevalier Jackson's most recent models, and each is supplied with a spare light carrier, i.e., 2 light carriers and 2 lamps. All the models have been redesigned with a view to rendering them more easily cleansed; all the crevices and corners for the dirt have been taken away.

To ensure better visibility the tips of the forceps are black.

The Howarth-Jackson's Instruments are less expensive than other American or English models, and a further economy bas been effected by rendering the instrument tips interchangeable, thus reducing the number of forceps handles and tips required.

The lamps are 2.5 volt and more durable than the usual models.

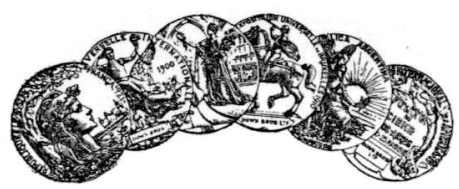

Telegrams-" DOWN, LONDON."

Telephone-HOP 4400 ( 4 lines).
Manufactured only by

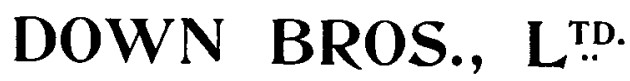

SURGICAL INSTRUMENT MAKERS

\section{1 and 23 ST THOMAS'S STREET}

LON DON, S.E. 1

(Opposite Guy's Hospital) 


\title{
4TH EDITION. REVISED AND ENLARGED. LEWIS'S PRACTICAL SERIES \\ DISEASES OF THE NOSE AND THROAT \\ By HERBERT TILLEY, B.S.(Lond.), F.R.C.S.(Eng.), Surgeon, Ear and Throat Department, University College Hospital; Teacher of Laryngology and Otology, Lniversity of London. With numerous lliustrations, including 74 Plates. Demy $8 v 0$. \\ 28s. net. Postage Is., broad Is. 3d. Extracts from Press Notices.
}

"The work is so comprehensive that it should be a valuable book of reference, whilst it is not too large to serve as an ordinary textmbook."-British Medical Journal.

"We have no hesitation in recommending his book to tho practitioner as well as to the prospective specialist." - The Lancet.

"The suthor is to be congratulated upon his work; as a text-book it is one of the best apon the snbject ; . . displays tho master mind of an accomplished teacher."-Medical Press.

LONDON: H. K. LEWIS \& C0. LTD., 136 Gower Street, and 24 Gower Place, W.C. 1. Telegrams : "Publicavit, Eusroad, London." Telephone: Museum 1072.

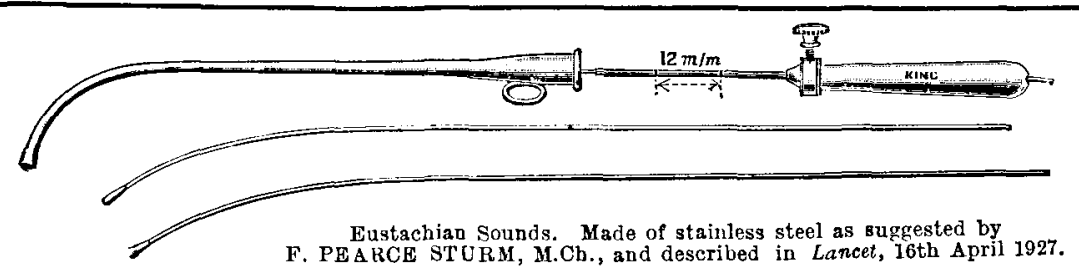

A. CIARIES TING, LTD. SuRaical Inhtrument Makers

34 DEVONSHIRE STREET, LONDON, W.I Telephone-Langham 2264

\section{THE GOLDEN SQUARE THROAT, NOSE AND EAR HOSPITAL \\ LONDON, W. 1}

HONORARY MEDICAL STAFF

Mr T. JEFFERSON FAULDER Surgeons

Mr GEORGE W. BADGEROW

Mr Lionel Colledge

Mr G. W. DAwSON

Mr GiLBERT CHUBB

Mr THEODORE JUST

\author{
Mr ORMEROD Assistant Surgeons \\ Mr BEDFORD RUSSELL Mr SANDIFORD
}

The Hospital has recently undergone very extensive reconstruction and extension, and now has 73 beds for In-patients and an annual Out-patient attendance of about 40,000.

\section{CLINICAL INSTRUCTION}

Clinical Instruction in the Diagnosis and Treatment of Diseases of the Ear, Nose and Throat is daily given in the Out-patient Department from 2 to 5 p.m. On Tuesdays and Fridays from 6.30 to 8 p.m. also. Major operations are performed daily, except Mondays, in the In-patient Operating Theatres. Minor operations are performed in the Out-patient Department by the Assistant Surgeons on four mornings a week.

Practitioners and Medical Students are admitted to the practice of the Hospital, and Clinjcal Assistants, whose duty it is to assist the staff, are appointed from time to time among them. For further information apply to the Dean, THEODORE JUST. 


\section{CONTENTS}

The Alleviation of Chronic Deafness. Editorial . . . 241

DEAF-MUtism With Bilateral Lesion of the AUditory SeNSORY

Areas. J. S. Fraser, M.B., F.R.C.S.E., and Sarah H. Nelson, M.B., Ch.B.

Posterior (Mastoid) Drainage in acute Suppuration of the Middle-

EAR. Dan McKenzie, M.D. . . . . . . . .

Notes on Paracusis Willisil from THE FekeNS INSTIIUIE OF OTO-

Laryngology. Somerville Hastings, M.S., and Gordon R. Scarff,

F.R.C.S.E. • • • • • • • • •

The Surgical Approach to i he Ethmoid. C. A. Verge, M.B., Ch.M.

(Sydney), F.R.C.S.E. . . . . . . . .

CLINICAL RECORD-

Secondary Hæmorrhage after Diathermy Operation. E. A. Hallas, Vejle, Denmark .

Societies' Proceedings-

Royal Society of Medicine-Section of Otology . $\quad . \quad$. $\quad . \quad 279$

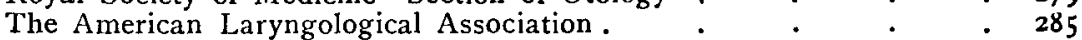

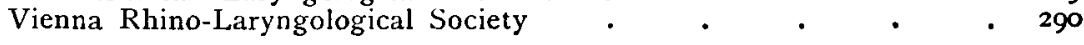

ABSTRACTS-

The Ear

The Laryn

Endoscopy for Foreign Bodies Speech Vibration.

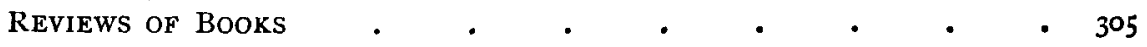

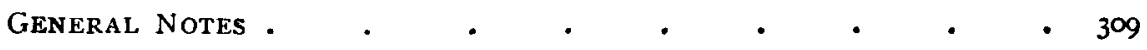

In the Press

Ready Shortly

\section{THE TONSILS AND ADENOIDS AND THEIR DISEASES}

\section{Including the Part they Play in Systemic Diseases}

By IRWIN MOORE, M.B. C.M.

Late Honorary Surgeon to the London Throat Hospital for Diseases of the Throat, Nose and Ear, Great Portland Street; and also to the Hospital for Diseases of the 1 hroat, Golden Square, London, W.

\section{Demy 8vo. Fully Illustrated. Price 21s. net}

This book is the outcome of much practical private and hospital experience, and embodies a number of papers which the author has contributed to various medical journals during recent years, dealing with the important subject of enlarged or diseased tonsils and adenoids-their menace to health, the operative technique for their removal, and the control of hæmorrhage, during and after removal.

WM. HEINEMANN (MEDICAL BOOKS) LTD. 99 Great Russell Street, London, W.C.I. 